\title{
A field evaluation of long-term effects of PIT tagging
}

Skov, Christian; Hansen, Joan Holst; Baktoft, Henrik; Brönmark, Christer; Brodersen, Jakob; Chapman, Ben B; Hansson, Lars-Anders; Hulthén, Kaj; Nilsson, P Anders

Published in:

Journal of Fish Biology

Link to article, DOI:

$10.1111 / \mathrm{jfb} .14292$

Publication date:

2020

Document Version

Peer reviewed version

Link back to DTU Orbit

Citation (APA):

Skov, C., Hansen, J. H., Baktoft, H., Brönmark, C., Brodersen, J., Chapman, B. B., Hansson, L-A., Hulthén, K., \& Nilsson, P. A. (2020). A field evaluation of long-term effects of PIT tagging. Journal of Fish Biology, 96(4), 10551059. https://doi.org/10.1111/jfb.14292

\section{General rights}

Copyright and moral rights for the publications made accessible in the public portal are retained by the authors and/or other copyright owners and it is a condition of accessing publications that users recognise and abide by the legal requirements associated with these rights.

- Users may download and print one copy of any publication from the public portal for the purpose of private study or research.

- You may not further distribute the material or use it for any profit-making activity or commercial gain

- You may freely distribute the URL identifying the publication in the public portal 


\section{A field evaluation of long-term effects of PIT tagging}

Christian Skov*1 ${ }^{1}$ Joan Holst Hansen ${ }^{1}$, Henrik Baktoft ${ }^{1}$, Christer Brönmark ${ }^{2}$, Jakob Brodersen ${ }^{3}$, Ben

B. Chapman ${ }^{4}$, Lars-Anders Hansson², Kaj Hulthén ${ }^{2}$, \& P. Anders Nilsson²

${ }^{1}$ DTU Aqua, National Institute of Aquatic Resources, Section for Inland Fisheries and Ecology

Vejlsøvej 39, DK-8600 Silkeborg, Denmark

2 Department of Biology - Aquatic Ecology, Ecology Building, Lund University, SE-223 62 Lund,

Sweden.

${ }^{3}$ Department of Fish Ecology and Evolution, EAWAG Swiss Federal Institute of Aquatic Science and Technology, Center for Ecology, Evolution and Biogeochemistry, Kastanienbaum, Switzerland.

${ }^{4}$ Evolution and Genomic Sciences Division, School of Biological Sciences, University of

Manchester, M13 9PT, UK.

${ }^{*}$ Corresponding author

Cnristian Skov

DTU Aqua, National Institute of Aquatic Resources, Section for Inland Fisheries and Ecology

Vejlsøvej 39, DK-8600 Silkeborg, Denmark

ck@aqua.dtu.dk

Running title; A field evaluation of PIT tagging of freshwater fish

This article has been accepted for publication and undergone full peer review but has not been through the copyediting, typesetting, pagination and proofreading process which may lead to differences between this version and the Version of Record. Please cite this article as doi: 10.1111/jfb.14292 
Funding information

C.S., J.H.H. \& H.B. were supported by the Danish National Fishing License Funds.

Acknowledgements

We thank landowners for allowing us access to the lakes and H.-J. A. Christensen, M. Holm, M.

Carøe, J. Skole, A, Svarer and J. Dolby for technical assistance in the Danish lakes.

Authors contributions

C.S. and A.N. conceived the study and drafted the manuscript, C.S., J.B., C.B., L.A.H., J.H.H., B.B.C., K.H. and A.N. did the fieldwork. H.B. analysed the data and produced the figure and table content. All authors engaged in preparing the final draft of the manuscript and revised the final version.

\section{ARCID}

Skov ck@aqua.dtu.dk ORCID 0000-0002-8547-6520; ResearcherID: X-6511-2019

Hansen: joanholsthansen@gmail.com; ORCID: 0000-0003-4500-9749

Baktoft: hba@aqua.dtu.dk; ORCID: 0000-0002-3644-4960; ResearcherID: E-6581-2011

Brönmark; christer.bronmark@biol.lu.se; ORCID 0000-0002-5203-8727

Brodersen jakob.brodersen@eawag.ch ORCID: 0000-0003-2060-6379

Chapman ben.chapman-2@manchester.ac.uk 
Hansson lars-anders.hansson@biol.lu.se ORCID 0000-0002-3035-1317

Hulthén kaj.hulthen@biol.lu.se ORCID 0000-0003-4360-5555

Nilsson: anders.nilsson@biol.lu.se, ORCID: 0000-0002-3541-9835, ResearcherID: H-6836-2014 


\section{Abstract}

PIT-tagging is commonly used in behavioural studies of fish, although long-term evaluations of effects from tagging under natural conditions are scarce. We PIT-tagged common bream Abramis brama, European perch Perca fluviatilis, pike Esox lucius and roach Rutilus rutilus, released them in their lakes of origin and recaptured them after 103-3269 days. Overall, tagged fish did not differ in condition from non-tagged fish, except for small $R$. rutilus that weighed less in one lake in one year. We conclude that PIT-tagging in general has negligible long-term effects on fish condition. 
Studies of fish behaviour hold important keys to ecological and behavioural questions, e.g. how the behaviour of individual fish affects higher-order processes, as well as how individuals respond to environmental change. There are various technological approaches to track and monitor individual fish in the field, including high-end telemetry technologies such as radio, acoustic, Data Storage Tags (DST) and/or Pop-up Satellite Archival Tags (PSATs) (Thorstad et al., 2013), as well as lowerend tagging methods (Floy and T-bar tags), which are cheap, long lived, and readily identify individuals (Guy et al., 1996). Passive Integrated Transponder (PIT) tags are low-cost, long-life tags that allow for highly replicated monitoring of individual behaviour (Thorstad et al., 2013). PIT tags have been increasingly used in recent years, for example in studies on long-term movement patterns (e.g. Brodersen et al., 2019), effects of predation risk (e.g. Skov et al. 2013), body size and condition (e.g. Heim et al., 2014) and environmental cues (e.g. Haraldstad et al., 2017).

It is generally assumed that PIT tags have no or negligible effects on individual survival, behaviour and/or performance, as long as a certain tag/fish mass ratio is not exceeded. However, past evaluations are contradictory as some studies report adverse effects (e.g. Larsen et al., 2013), while others report no or minor effects (e.g. Stakénas et al., 2009, Hühn et al., 2014). Most of these results are from controlled laboratory or mesocosm studies that focus on short-term effects (e.g. Skov et al., 2005), whereas studies on longer-term effects are still scarce (but see Ashton et al., 2014). Moreover, possible adverse effects of PIT tagging are likely to be species dependent, e.g. some species may be more susceptible than others (Stakénas et al. 2009), indicating a need for speciesspecific evaluations. Here we evaluate long-term (103 to 3269 days after tagging), species- and sizespecific effects of PIT tags on fish body condition, i.e. length-specific weight, after release into their 
natural environment. We focus on four species, including common bream Abramis brama L., perch Perca fluvitatilis L., pike Esox lucius L. and roach Rutilus rutilus L. from four lakes in southern Scandinavia. We compared the length-specific weight of 442 PIT-tagged and subsequently recaptured individuals with that of untagged conspecific reference fish caught during the recapture events. We predicted that if PIT tagging have no adverse long-term effects, the length-specific weight of tagged fish should mirror that of untagged conspecifics.

Fish were mainly caught by electrofishing, but also by seining and gillnetting, in four lakes, Krankesjön in Sweden and Loldrup Sø, Viborg Sø and Søgård Sø in Denmark, during SeptemberNovember (occasionally in winter and spring) from 2003 to 2015 (Table 1). Ethical concerns on experimental animal treatment were followed under permission from the Danish Animal Experiments Inspectorate and permission (M14-04) from the Malmö/Lund Ethical Committee. Fish, varying from 14.1 g to 10600 g, were PIT tagged (Texas Instruments, RI-TRP-RRHP, half duplex, $134 \mathrm{kHz}, 23.1 \mathrm{~mm}$ long, $3.85 \mathrm{~mm}$ diameter, $0.6 \mathrm{~g}$ ) under anaesthetization with bensocain, following Skov et al. (2005). This corresponds to a tag/fish mass ratio of 0.0058-4.26\%. Yearly sampling campaigns to recapture tagged fish took place in each of the four study lakes. During the campaigns we also captured, measured (total length, weight) and thereafter tagged additional fish, which were used as reference fish for comparisons with recaptured fish (i.e. comparing fish individuals that had not been tagged with fish individuals that had carried their tags for substantial time). Weights of recaptured tagged fish were corrected for PIT tag weight (0.6 g). 
The healing of the incision wounds was always visually inspected upon recapture and no signs of inflammations or infections were found. For pike, healing appeared to be very fast and already after a few weeks it was difficult to identify the incision. In roach, incision wounds closed up shortly after tagging, but were normally visible until after the first growth season. After the fish had experienced one growth season (around six months out of the year when temperature is above $10^{\circ} \mathrm{C}$ ), the incision wounds were generally difficult to recognize after regeneration of scales. Fish were collected as part of other research projects and fish were generally not sacrificed, but roach and bream sampled from Lake Søgaard Sø in 2013/2014 and 2014/2015 were sacrificed as part of a lake restoration project (Skov et al., 2019). Surgical procedures were performed when tagging the fish, but this did not cause severe distress or lasting harm (e.g. Skov et al., 2005; results from the present study).

We statistically compared the mass of each recaptured fish with the predicted mass from a lengthmass relation obtained from conspecific reference fish from the day and lake of recapture using species-specific multilevel models. If tagging does not affect fish status, deviations of observed from predicted length-specific mass $\left(\mathrm{E}=\log \left(\mathrm{M}_{\mathrm{obs}}\right)-\log \left(\mathrm{M}_{\mathrm{pred}}\right)\right)$ of tagged fish should mirror that of reference fish. Modelling of the length-mass relationship was based on the standard allometric equation $M=A \cdot L^{B}$, equivalent to $\log (M)=\log (A)+B \cdot \log (L)$. As parameters $A$ and $B$ can vary between populations (i.e. lakes) and potentially also temporally within populations, the model was extended to allow for this variation. The number of replicate lakes was relatively low, so lakespecific parameters $\log \left(A_{j}\right)$ and $B_{j}$ were estimated, whereas the effect of sampling event was added as a random effect to both $\log \left(\mathrm{A}_{\mathrm{j}}\right)$ and $\mathrm{B}_{\mathrm{j}}$ estimations. Additionally, variance was allowed to vary 
between sampling events and as a function of length by including a variance structure. Thus, for each of the four species, the following model was fitted:

$$
\begin{aligned}
& \log \left(\mathrm{M}_{\mathrm{ijk}}\right) \sim \mathrm{N}\left(\mu_{\mathrm{ijk}}, \sigma_{\mathrm{k}}^{2} \cdot \log \left(\mathrm{L}_{\mathrm{ijk}}\right)\right) \\
& \mu_{\mathrm{ijk}}=\log \left(\mathrm{A}_{\mathrm{j}}\right)+\mathrm{a}_{\mathrm{k}}+\left(\mathrm{B}_{\mathrm{j}}+\mathrm{b}_{\mathrm{k}}\right) \cdot \log \left(\mathrm{L}_{\mathrm{ijk}}\right) \\
& \mathrm{a}_{\mathrm{k}} \sim \mathrm{N}\left(0 ; \sigma_{\mathrm{a}}^{2}\right) \\
& \mathrm{b}_{\mathrm{k}} \sim \mathrm{N}\left(0 ; \sigma_{\mathrm{b}}^{2}\right)
\end{aligned}
$$

In short, the model states that $\log$ (mass) of fish $i$ from lake $j$ captured in event $k$ is normally distributed $(\sim \mathrm{N})$ with mean $\mu_{\mathrm{ijk}}$ and variance dependent on sampling event and length $\left(\sigma_{\mathrm{k}}{ }^{2}\right.$. $\left.\log \left(\mathrm{L}_{\mathrm{ijk}}\right)\right)$. The predictor function $\mu_{\mathrm{ijk}}$ allows lake specific variation of both parameters as well as random variation specific to sampling event around $\log \left(A_{j}\right)$ and $B_{j}$ through the random variables $a_{k}$ and $b_{k}$. Each of these are assumed to be normally distributed with a mean of zero and variance $\sigma_{\mathrm{a}}{ }^{2}$ and $\sigma_{\mathrm{b}}^{2}$, respectively.

Markov Chain Monte Carlo (MCMC) techniques were employed using JAGS (Plummer, 2003) to estimate the parameters of the model. Diffuse normal priors were used for model parameters $A_{j}$ and $\mathrm{B}_{\mathrm{j}}$ and Half-Cauchy(25) priors were used for variance terms $\sigma_{\mathrm{k}}, \sigma_{\mathrm{a}}$ and $\sigma_{\mathrm{b}}$. Three chains with 50000 iterations in each were run with burn-in of 10000 iterations and a thinning rate of 10, resulting in 12000 saved iterations. Within each MCMC iteration, $\log \left(\mathrm{M}_{\mathrm{ijk}}\right)$ was simulated from the model for reference and recaptured fish and subtracted from observed values of $\log \left(\mathrm{M}_{\mathrm{ijk}}\right)$ to obtain $\mathrm{E}_{\mathrm{ijk}}$. For all saved iterations, posterior values of $E_{\mathrm{ijk}}$ were modelled as a function of $\log \left(\mathrm{L}_{\mathrm{ijk}}\right)$ for reference and recaptured fish separately using generalized additive models (GAM). Basis for the GAMs was thin plate regression splines and the dimension was restricted to five to prevent over-fitting. The fitted GAMs were subsequently used to predict values of E for reference and recaptured fish using 
artificial data sets of $\log (\mathrm{L})$ truncated to span the range of length of recaptured fish. Finally, predicted E of recaptured fish were subtracted from predicted $\mathrm{E}$ of reference fish to enable assessment of length-specific tagging effects. Statistical analyses were performed in R (v. 3.5.2; R Core Team (2018)) using packages mgcv (v. 1.8-26; Wood (2011)) and R2jags (v. 0.5-7; Su \& Yajima (2015)).

The 442 PIT-tagged fish (Table 1) were recaptured between 103 and 3269 days after tagging, along with the capture of 10826 untagged reference fish (Table 1), and the results show that wild fish recaptured up to nine years after tagging generally showed no difference in length-specific body mass compared to simultaneously sampled untagged individuals within the length classes investigated (Figure 1). This suggests that body condition and therefore the wellbeing of PIT tagged fish within these species and size ranges are not negatively affected by tagging, an interpretation based on the assumption that length-specific weight reflects the wellbeing of a fish (e.g. Bolger \& Connolly, 1989). The investigated species belong to different families (Cyprinidae, Percidae, Esocidae) and to different functional feeding groups. Common bream and roach are actively foraging for benthic and planktonic invertebrates, perch is an active forager that goes through an ontogenetic diet shift where preferred prey changes with age/size (zooplankton to benthic invertebrates to fish), whereas pike is mainly a sit-and-wait-forager feeding on fish. Thus, this suggests that the results to some extent could be generalized across taxa, functional groups, sizes and lakes (but see Stakénas et al., 2009). The only exception to this general pattern was found in roach where the smallest $(<15 \mathrm{~cm})$ tagged and recaptured individuals showed a lower $(2-5 \%)$ lengthspecific body weight compared to untagged conspecifics (Figure. 1). However, post-hoc analyses 
revealed that this result was strongly driven by roach recaptured in one particular lake in one particular year (Lake Søgaard in 2014, Figure 1). A small fish will have a higher tag to body-mass ratio than larger fish, and it is thereby not surprising that this effect was found in the smallest size class of roach. In some studies, the $2 \%$ rule, i.e. that the weight of the tag should constitute $\leq 2 \%$ of the body weight, is applied as a rule of thumb when setting the minimum size of fish that should be tagged (Jepsen et al., 2005). However, this rule is challenged by examples of no adverse effects of even larger tags (Jepsen et al., 2005). In our tagging programme we have generally accepted tag to body-weight ratios up to 3\%, i.e. fish carrying the $0.6 \mathrm{~g}$ PIT tag should weigh more than $20 \mathrm{~g}$. Interestingly, the $2 \%$ rule implies that fish should weigh at least $30 \mathrm{~g}$, which is close to the average weight (35.8 g) of 15 cm roach in our study. The tagged roach in Søgård in 2014 had an average length of 16.5 cm, which resembles the overall average tagging size in lake Søgård Sø $(16.6$ cm, Table 1). Moreover, when data from Søgård 2014 were removed, recaptures of roach with tag to body-weight ratios above $2 \%$ were still present in the data, i.e. from other study years and/or lakes. Thus, a particular low tag to body mass ratio in Søgård 2014 could not explain the negative effects on Søgård roach in that year. We also explored if the time from tagging to recapture in Søgård 2014 stood out from other years, i.e. if the healing periods were extraordinarily short. However, this seemed not to be the case as average number of days between tagging and recapture in 2014 was only slightly less (253 days) than the average for all study years in Lake Søgård (268 days, Table 1). Further, tagging procedures were consistent between lakes and years leaving us with no immediate explanation for the difference in 2014. Notwithstanding, the effect size was relatively small suggesting that the magnitude of the potentially related biological effects could also be relatively minor. Future studies could explore the effects of a reduced length-specific weight of $2-5 \%$ on e.g. 
feeding and antipredator behaviour of tagged roach. Moreover, although our findings suggest that adverse tagging effects are low, a relevant next step in our understanding of tagging effects would be to evaluate if and to what extent PIT tagging affects long-term survival, which the present study design did not allow us to explore.

We also observed that roach between 175 and $250 \mathrm{~mm}$ had a 95\% probability of having a higher body mass than untagged conspecifics, e.g. up to 5\% deviation (Figure 1). A trend towards a similar pattern was observed for larger perch (Figure 1). We can only speculate on the reasons behind these patterns, but it is possible that individuals with high capacity for growth and body condition are simply more likely to survive to be recaptured.

Overall, the results from this study on long-term effects of PIT-tagging on multiple species from multiple lakes show that PIT technology can be used in long-term studies of individual behaviour in the wild without causing negative effects on fish body condition. The only exception to this general pattern was found in smaller roach individuals and only evident in one lake and during one year.

\section{References}

Ashton, N. K., Anders, P. J., Young S. P., \& Cain K. D. (2014). Coded Wire Tag and Passive Integrated Transponder Tag Implantations in Juvenile Burbot, North American Journal of Fisheries Management, 34, 391-400, DOI:10.1080/02755947.2014.882458

Bolger T., \& Connolly P. L. (1989). The selection of suitable indexes for the measurement and analysis of fish condition. Journal of Fish Biology, 34, 171-182. 
Brodersen, J., Hansen, J. H., \& Skov, C. (2019). Partial nomadism in large-bodied bream (A bramis brama). Ecology of Freshwater Fish, 28, 650-660. DOI: 10.1111/eff.12483.

Guy, C. S., Blankenship, H. L., \& Nielsen, L. A. (1996). Tagging and Marking. In B.R. Murphy, D.W. Willis (Eds). Fisheries Techniques (2nd ed., pp. 353-383). Bethesda, Maryland, American Fisheries Society.

Haraldstad, T., Kroglund, F., Kristensen, T., Jonsson, B., \& Haugen, T. O. (2017). Diel migration pattern of Atlantic salmon (Salmo salar) and sea trout (Salmo trutta) smolts: an assessment of environmental cues. Ecology of Freshwater Fish, 26, 541-551. doi:10.1111/eff.12298.

Heim, K. C., Wipfli, M. S., Whitman, M. S, Seitz, A. C. (2014). Body size and condition influence migration timing of juvenile arctic grayling. Ecology of Freshwater Fish, 25, 156-166. doi:

10.1111/eff.12199

Hühn, D., Klefoth, T., Pagel, T., Zajicek, P., \& Arlinghaus, R. (2014). Impacts of external and surgery-based tagging techniques on small northern pike under field conditions. North American Journal of Fisheries Management, 34, 322-334.

Jepsen, N., Schreck, C., Clements, S. \& Thorstad, E. B. (2005). A brief discussion on the 2\% tag/bodymass rule of thumb. In M.T. Spedicato, G. Lembo, G. Marmulla (Eds.) Aquatic telemetry: advances and applications. Proceedings of the Fifth Conference on Fish Telemetry held in Europe (pp. 255-259). Rome, FAO/COISPA.

Larsen, M. H., Thorn, A. N., Skov, C., \& Aarestrup, K. (2013). Effects of passive integrated transponder tags on survival and growth of juvenile Atlantic salmon Salmo salar. Animal Biotelemetry, 1, 19. DOI: 10.1186/2050- 3385-1-19. 
Plummer, M. (2003). JAGS: A program for analysis of Bayesian graphical models using Gibbs sampling. Paper presented at the Proceedings of the 3rd international workshop on distributed statistical computing.

R Core Team (2018). R: A language and environment for statistical computing. R Foundation for Statistical Computing, Vienna, Austria. URL https://www.R-project.org/.

Skov, C., Brodersen, J., Brönmark, C.., Hansson, L-A., Hertonsson, P., \& Nilsson, P. A. (2005). Evaluation of PIT-tagging in cyprinids. Journal of Fish Biology, 67, 1195-1201.

Skov, C, Chapman, B. B., Baktoft, H., Brodersen, J., Brönmark, C., Hansson, L-A., Hulthén, K., \& Nilsson, P. A. (2013). Migration confers survival benefits against avian predators for partially migratory freshwater fish. Biology Letters, 9, 20121178. http://dx.doi.org/10.1098/rsbl.2012.1178 Skov, C., Hansen, J. H., Baktoft, H., Brodersen, J., Brönmark, C., Hansson, L-A., Hulthén, K., Chapman, B. B., \& Nilsson, P. A. (2019). Biomanipulating streams: a supplementary tool in lake restoration. Hydrobiologia, 829, 205-216. https://doi.org/10.1007/s10750-018-3832-4

Stakénas, S., Copp, G. H., \& Scott D. M. (2009) Tagging effects on three non-native fish species in England (Lepomis gibbosus, Pseudora,sbora parva, Sander lucioperca) and of native Salmo trutta. Ecology of Freshwater Fish, 18, 167-176.

Thorstad, E. B., Rikardsen, A. H., Alp, A., \& Økland, F. (2013). The use of electronic tags in fish research—an overview of fish telemetry methods. Turkish Journal of Fisheries and Aquatic Sciences, 13, 881-896.

Wood, S. N. (2011). Fast stable restricted maximum likelihood and marginal likelihood estimation of semiparametric generalized linear models. Journal of the Royal Statistical Society (B), 73, 3-36. 
Su, Y-U., \& Yajima, M. (2015). R2jags: Using R to Run 'JAGS'. R package version 0.5-7. https://CRAN.R-project.org/package=R2jags 

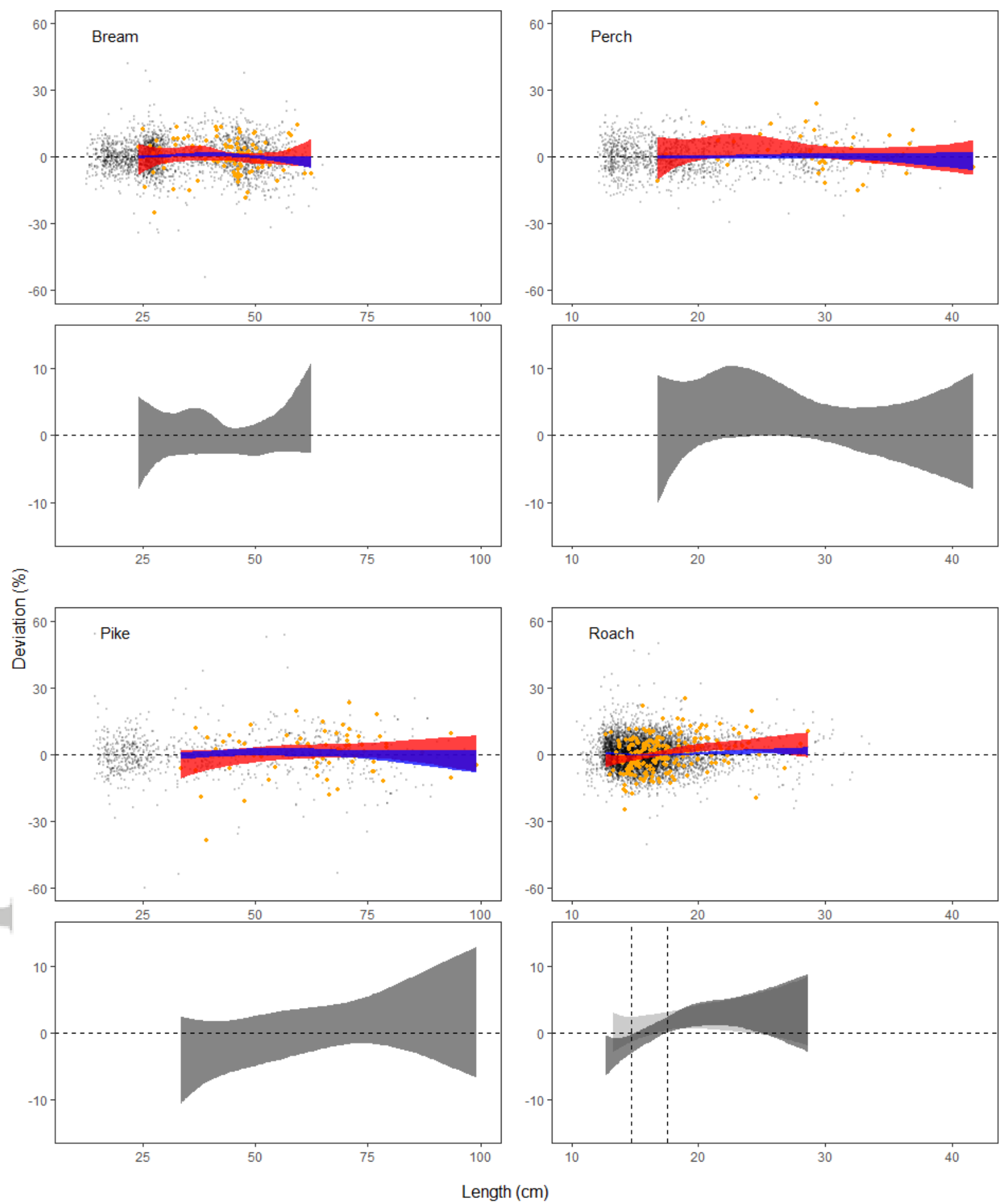
Figure 1. Mean deviation of observed from predicted length-specific body mass for each individual fish (points) and 95\% credible interval of GAMs (coloured areas) for bream, perch, pike and roach. Black data points and blue area are reference fish, orange data points and red area are recaptured fish. Lower panels for each species show 95\% credible intervals for the difference between GAMs for reference and recaptured fish. Negative values indicate that recaptured fish overall had lower length-specific body mass then reference fish. In the figure for roach, vertical lines indicate length interval at which difference was zero $(16.3(14.7$ - 17.5) cm; posterior mean and 95\% credible interval), and the lighter grey 95\% area shows model results after removing roach data from Søgård Sø in 2014, indicating no adverse effects on small roach. 
Table 1. Description of the four study lakes as well as number of recaptures (Recaptures (n), average length of recaptures (Recapt. avr. length), the average number of days between tagging and recapture (Recapt. $\Delta$ time), the number of days (Sampling days) where recaptures were compared with untagged reference fish, and the number of untagged reference fish (Reference fish (n)) that were used for comparison with recaptures for each of the four species in each of the four lakes. SD = standard deviation. Lake Viborg consist of a northern $(\mathrm{N})$ and a southern basin $(\mathrm{S})$ separated by a 75m long and 6-12m wide channel without barriers.

\section{Lake Viborg Lake Søgård Lake Krankesjöen Lake Loldrup}

\begin{tabular}{|c|c|c|c|c|c|}
\hline$\stackrel{0}{1}$ & Area & $\begin{array}{l}\mathrm{N} 1.23 \mathrm{~km}^{2}, \\
\mathrm{~S} 1.46 \mathrm{~km}^{2}\end{array}$ & $0.26 \mathrm{~km}^{2}$ & $3.4 \mathrm{~km}^{2}$ & $0.39 \mathrm{~km}^{2}$ \\
\hline & Position & $56^{\circ} 26^{\prime} \mathrm{N}, 9^{\circ} 25^{\prime} \mathrm{E}$ & $55^{\circ} 29^{\prime} \mathrm{N}, 9^{\circ} 19^{\prime} \mathrm{E}$ & $55^{\circ} 42^{\prime} \mathrm{N}, 13^{\circ} 28^{\prime} \mathrm{E}$ & $56^{\circ} 29^{\prime} \mathrm{N}, 9^{\circ} 26^{\prime} \mathrm{E}$ \\
\hline 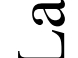 & Mean depth & N 7.0 m, S 3.4 m & $1.6 \mathrm{~m}$ & $0.6 \mathrm{~m}$ & $1.2 \mathrm{~m}$ \\
\hline & Recaptures (n) & 22 & 27 & 0 & 58 \\
\hline & $\begin{array}{l}\text { Recapt. avr. } \\
\text { length (+/- SD) }\end{array}$ & $41.8(8.8)$ & $40.1(11.3)$ & NA & $46.0(6.1)$ \\
\hline & $\begin{array}{l}\text { Recapt. } \Delta \text { time } \\
(+/- \text { SD) }\end{array}$ & 925.6 (533.5) & 709.2(612.7) & NA & 1151.7 (874.1) \\
\hline & Sampling days & 9 & 7 & NA & 10 \\
\hline & Reference fish (n) & 919 & 607 & 0 & 1042 \\
\hline & Recaptures (n) & 6 & 34 & 0 & 2 \\
\hline & $\begin{array}{l}\text { Recapt. avr. } \\
\text { length (+/- SD) }\end{array}$ & 29.6(6.3) & $29.5(5.8)$ & NA & $24.9(4.6)$ \\
\hline J & $\begin{array}{l}\text { Recapt. } \Delta \text { time } \\
(+/- \text { SD) }\end{array}$ & $607.0(294.0)$ & $586.0(321.6)$ & NA & $371.5(0.7)$ \\
\hline بـ & Sampling days & 3 & 10 & NA & 2 \\
\hline & Reference fish (N) & 230 & 1075 & 0 & 162 \\
\hline & Recaptures (n) & 2 & 45 & 1 & 24 \\
\hline$\frac{1}{10}$ & $\begin{array}{l}\text { Recapt. avr. } \\
\text { length (+/- SD) }\end{array}$ & $62.6(4.8)$ & $60.9(15.0)$ & 39.1 (NA) & $66.2(14.4)$ \\
\hline & $\begin{array}{l}\text { Recapt. } \Delta \text { time } \\
(+/- \text { SD) }\end{array}$ & $727.0(520.4)$ & 902.7 (541.3) & 349 (NA) & 913.5 (536.3) \\
\hline
\end{tabular}




\begin{tabular}{|c|c|c|c|c|c|}
\hline & \multirow[b]{2}{*}{33} & \multirow{2}{*}{$\begin{array}{l}9 \\
439\end{array}$} & \multirow{2}{*}{$\begin{array}{l}1 \\
58\end{array}$} & \multirow{2}{*}{$\begin{array}{l}7 \\
387\end{array}$} \\
\hline & & & & \\
\hline \multirow{5}{*}{$\underset{\sigma}{\tilde{\sigma}}$} & $\begin{array}{l}\text { Sampling days } \\
\text { Reference fish (n) }\end{array}$ & 7 & 143 & 60 & 11 \\
\hline & $\begin{array}{l}\text { Recapt. avr. } \\
\text { length (+/- SD) }\end{array}$ & $25.2(3.5)$ & $16.6(2.5)$ & $17.9(2.6)$ & $19.0(2.9)$ \\
\hline & $\begin{array}{l}\text { Recapt. } \Delta \text { time } \\
(+/- \text { SD) }\end{array}$ & $579.6(289.0)$ & $267.9(268.6)$ & 391.5 (228.1) & 594.8 (306.1) \\
\hline & Sampling days & 5 & 21 & 4 & 6 \\
\hline & Reference fish (n) & 605 & 2820 & 550 & 1899 \\
\hline
\end{tabular}

